\title{
PENGARUH TINGKAT PENDIDIKAN ORANG TUA TERHADAP MOTIVASI BELAJAR MATEMATIKA SISWA DI KELAS IV SD NEGERI 064025 KECAMATAN MEDAN TUNTUNGAN TAHUN PEMBELAJARAN 2018/2019
}

\section{KRISTINA PASARIBU (PGSD FKIP UNIVERSITAS KATOLIK SANTO THOMAS)}

\begin{abstract}
The research is aimed to know the influence of parent's education level on motivating the student's match score year 2018/2019. The research is using the quantitative research by corelationmethode. The population in this study were all students of SD 064025 in Medan TuntunganSubdistrict as many as 734 people. The sample is 124 people with a sampling technique that is Simple Random Sampling.Data in research obtained is observations, questionnaire, and study documentation. The analytical technique used is a test of the prerequisite for analysis and hypothesis testing using the Program Statistics for Social Science (SPSS) assistance. From the data analysis data, it is found that there is a linear relationship between parent's education level on motivating the student's this is supported by the results of testingt $t_{\text {count }}>t_{\text {table }}$ and $t$ test is done at the level ( $\alpha=$ $0,05)$ that $t_{\text {count }}>t_{\text {tablewas }}$ SD with SMP $(2,2937>1,6675)$, SD with SMA $(5,3917$ $>1,6722)$, SD with D3 (2,2635 > 1,6779), SD with $\mathrm{S} 1(2,0929>1,6810)$ this proves that $H_{a}$ is accepted. Then there isinfluencebetweenparent's education level on motivating learn the student's in the fourth grade SD Negeri 064025 distric Medan Tuntungan.
\end{abstract}

Keywords: Parent's Education Level, Motivation The Of Study Student's.

\section{PENDAHULUAN}

\section{Latar Belakang Masalah}

Pendidikan mempunyai peranan yang sangat penting untuk menjamin kelangsungan hidup bangsa dan Negara, karena pendidikan merupakan wahana untuk meningkatkan dan mengembangkan kualitas sumber daya manusia. Pendidikan adalah segala pengalaman belajar yang berlangsung dalam segala lingkungan dan sepanjang hidup. Menurut Mudyahardjo (Kadir, 2017: 59), pendidikan adalah segala situasi hidup yang memengaruhi pertumbuhan dan perkembangan hidup. Pendidikan tidak pernah terpisah dari kehidupan manusia. Oleh karena itu, pendidikan sangat perlu untuk dikembangkan dari berbagai ilmu pengetahuan, karena pendidikan yang berkualitas akan meningkatkan kecerdasan 
bangsa. Melalui pendidikan manusia akan tumbuh dan berkembang sebagai pribadi yang utuh.

Pendidikan merupakan usaha yang dilakukan untuk membuat peserta didik berkembang. Pendidikan didapatkan dimana saja. Dalam dunia pendidikan, pendidikan terbagi atas dua yaitu pendidikan formal dan pendidikan non formal. Pendidikan formal sering kita sebut sekolah dan sedangkan pendidikan non formal yaitu pendidikan yang didapatkan di luar sekolah, seperti pendidikan dini yang kita dapatkan di rumah yaitu dari orangtua sendiri. Pendidikan formal dan non formal berperan penting dalam mendidik anak. Pendidikan formal diterima anak di sekolah sedangkan pendidikan non formal diterima anak di rumah

Salah satu mata pelajaran yang terdapat dalam pendidikan formal di sekolah adalah Matematika. Pembelajaran matematika merupakan salah satu bidang studi yang ada pada semua jenjang pendidikan, mulai dari tingkat sekolah dasar hingga perguruan tinggi, bahkan pembelajaran matematika sudah diajarkan di Taman Kanak-kanak secara informal. Untuk dapat memahami dan menguasai matematika diperlukan pendidikan yang baik, selain itu dalam pembelajaran diperlukan juga motivasi dari orangtua yang dapat mendorong atau memacu siswa dalam belajar, karena motivasi adalah hal yang sangat penting dalam pembelajaran.

Pada dasarnya pendidikan itu sangat berpengaruh dalam segala sendisendi kehidupan, demikian pula pendidikan orangtua mempengaruhi perkembangan anak. Berdasarkan data yang diperoleh mengenai tingkat pendidikan orangtua di SD 064025 kelas IV adalah sebagai berikut:

Tingkat Pendidikan Orangtua Siswa (Ayah)

\begin{tabular}{|c|l|c|c|}
\hline No & \multicolumn{1}{|c|}{ Tingkat Pendidikan Ayah } & Frekuensi & \% \\
\hline 1 & Tamat SD/Sederajat & 30 & $24,20 \%$ \\
\hline 2 & Tamat SMP/Sederajat & 40 & $32,26 \%$ \\
\hline 3 & Tamat SMA/Sederajat & 20 & $16,13 \%$ \\
\hline 4 & Tamat Diploma D3 & 19 & $15,32 \%$ \\
\hline 5 & Tamat S1 & 15 & $12,09 \%$ \\
\hline \multicolumn{2}{r|}{ Jumlah } & 124 & 100 \\
\hline
\end{tabular}


Berdasarkan data yang diperoleh peneliti mengenai tingkat pendidikan orang tua di SD 064025 kelas IV adalah sebagai berikut: tamatan SD 30 0rang, tamatan SMP 40 orang, tamatan SMA 20 orang, tamatan D3 19 orang, dan tamatan S1 15 orang. Hal ini menunjukkan bahwa di SD 064025 khususnya di kelas IV masih banyak orang tua yang pendidikannya masih rendah.

Tinggi rendahnya pendidikan orangtua akan berpengaruh terhadap cara dalam mendidik anak. Apabila tingkat pendidikan orangtua rendah maka rendah pula wawasan atau pengetahuan yang dimiliki orangtua dalam mendidik anak. Sebaliknya apabila tingkat pendidikan orang tua tinggi, maka semakin luas pula wawasan atau pengetahuan yang dimiliki orang tua dalam mendidik dan membimbing anaknya dan mereka ingin pendidikan anak-anaknya lebih tinggi atau setidaknya sama dengan pendidikan mereka.

Orangtua merupakan dasar pertama bagi pembentukan pribadi anak dan membentuk baik buruknya perilaku anak. Semenjak kehadirannya di muka bumi, setiap anak melibatkan peran penting orangtuanya, seperti peran pendidikan. Sebab orangtua merupakan lingkungan pertama dan utama yang dikenal anak dan secara alamiah memiliki kesempatan yang paling besar untuk mewarnai pribadi anak dimasa depan. Jadi dalam hal ini, orangtua hendaknya mendidik dan membimbing anaknya sejak lahir

Dalam sehari-hari, anak selain menjalani pendidikan formal, anak juga selalu terlibat secara dominan dengan pendidikan informal dalam keluarga. Seluruh komponen keluarga terutama orangtua memegang peranan yang besar terutama pada prestasi belajar anaknya. Pada diri setiap anak membutuhkan suatu dorongan untuk melakukan sesuatu dan suatu daya untuk meniru. Dengan dorongan ini anak dapat mengerjakan sesuatu yang dikerjakan oleh orang tuanya. Oleh karena itu, orang tua harus menjadi teladan yang baik bagi anak-anaknya. Orang tua selain sumber pemenuhan sarana prasarana belajar, juga sebagai pemberi motivasi belajar yang berdampak pada prestasi belajar. Motivasi adalah segala sesuatu yang mendorong untuk bertindak melakukan sesuatu. 
Motivasi belajar merupakan kekuatan mental yang mendorong terjadinya proses belajar. Motivasi belajar pada diri siswa dapat melemah, lemahnya motivasi atau tiadanya motivasi belajar akan melelehkan motivasi belajar dan mutu hasil belajar akan menjadi rendah. Oleh karena itu, motivasi belajar pada diri siswa perlu diperkuat terus-menerus. Motivasi yang timbul tentunya tidak hanya datang dari diri siswa sendiri maupun guru yang menciptakan suasana kelas dengan baik, melainkan cara orangtua dalam mendidik sangat mempengaruhi motivasi belajar siswa. Masing-masing orangtua tentunya memiliki cara yang berbeda-beda untuk mendidik atau mengarahkan anaknya.

Minimnya perhatian orangtua terhadap anak-anaknya membuat anak kurang mendapatkan motivasi dari dalam keluarga. Kebanyakan Orang tua terlalu sibuk dengan pekerjaannya sehingga waktu untuk berkomunikasi ataupun memperhatikan anaknya kurang, sementara yang kita ketahui bahwa orangtua memiliki peranan penting dalam segala aspek perkembangan anak. Anak yang kurang mendapatkan perhatian dari orantuanya akan memiliki dampak tersendiri bagi anak tersebut misalnya kurangnya motivasi anak dalam belajar dan bisa sampai kemerosotan dalam hal prestasi anak.

Berdasarkan pembahasan masalah tersebut peneliti melakukan penelitian untuk mengetahui "Pengaruh Tingkat Pendidikan Orangtua terhadap Motivasi Belajar Matematika di Kelas IV SD Negeri 064025 Kecamatan Medan Tuntungan Tahun Pembelajaran 2018/2019”.

\section{Identifikasi Masalah}

Berdasarkan uraian latar belakang di atas, dapat diidentifikasi beberapa masalah sehubungan dengan motivasi belajar siswa, antara lain:

1. Kurangnya perhatian dari orang tua yang mengakibatkan siswa kurang terrmotivasi dan malas belajar

2. Rendahnya tingkat pendidikan yang dimiliki orang tua mengakibatkan perbedaan motivasi belajar dalam diri siswa.

\section{Batasan Masalah}

Berdasarkan uraian pada latar belakang dan identifikasi masalah di atas, perlu dilakukan pembatasan masalah. Penelitian ini dibatasi pada masalah: 
pengaruh tingkat pendidikan orang tua terhadap motivasi belajar matematika siswa di kelas IV SD Negeri 064025 Kecamatan Medan Tuntungan tahun pembelajaran 2018/2019.

\section{Rumusan Masalah}

Adapun yang menjadi rumusan masalah dalam penelitian ini adalah:

1. Bagaimana tingkat pendidikan orangtua dan motivasi belajar siswa di kelas IV SD Negeri 064025 Kecamatan Medan Tuntungan?

2. Apakah ada pengaruh tingkat pendidikan orangtua terhadap motivasi belajar Matematika di kelas IV SD Negeri 064025 Kecamatan Medan Tuntungan?

\section{Tujuan Penelitian}

Adapun tujuan yang ingin dicapai dalam penelitian ini adalah:

1. Untuk mengetahui tingkat pendidikan orangtua dan motivasi belajar siswa di kelas IV SD Negeri 064025 Kecamatan Medan Tuntungan Tahun Pembelajaran 2018/2019.

2. Untuk mengetahui pengaruh tingkat pendidikan orangtua terhadap motivasi belajar siswa di kelas IV SD Negeri 064025 Kecamatan Medan Tuntungan Tahun Pembelajaran 2018/2019.

\section{Manfaat Penelitian}

Hasil penelitian ini diharapkan memberikan manfaat:

1. Bagi siswa, diharapkan untuk dapat lebih meningkatkan motivasinya dalam belajar matematika, sehingga diperoleh hasil belajar yang lebih baik.

2. Bagi guru, sebagai bahan masukan dalam memberikan dan meningkatkan motivasi siswa dalam belajar matematika terkait dengan tingkat pendidikan orang tua siswa.

3. Bagi Peneliti, sebagai bahan masukan untuk melakukan penelitian sesuai dengan masalah yang akan diteliti dan hasil penelitian ini diharapkan mampu memberi bekal dan wawasan bagi peneliti sebagai calon guru yang profesional dalam menerapkan model belajar yang menarik di Sekolah Dasar. 


\section{METODOLOGI PENELITIAN}

\section{Pendekatan dan Metode Penelitian}

Metode penelitian adalah cara atau jalan yang ditempuh sehubungan dengan penelitian yang dilakukan, yang memiliki langkah-langkah yang sistematis. Dalam penelitian ini, pendekatan yang digunakan adalah pendekatan kuantitatif yang metode pengambilan datanya yaitu korelasi. Menurut Siregar (2015: 201), penelitian korelasi adalah bilangan yang menyatakan kekuatan hubungan antara dua variabel atau lebih atau juga dapat menentukan arah dari kedua variabel.

\section{Tempat, kegiatan dan waktu penelitian}

\section{Tempat Penelitian}

Penelitian ini dilakukan pada siswa kelasi IV SD Negeri 064025 Kecamatan Medan Tuntungan tahun pembelajaran 2018/2019. Pemilihan lokasi ini didasarkan atas beberapa pertimbangan sebagai berikut:

1. Jumlah siswa di SD 064025 Kecamatan Medan Tuntungan cukup memadai untuk dijadikan subjek penelitian.

2. Di sekolah tersebut belum pernah diadakan penelitian yang sama dengan permasalahan yang akan diteliiti.

3. Sekolah tersebut dapat mewakili sekolah yang lain dengan penelitian yang sama.

4. Di SD 064025 Kecamatan Medan Tuntungan kebanyakan tingkat pendidikan orang tua para siswa masih rendah sehingga diadakan penelitian.

\section{Waktu dan Kegiatan Penelitian}

Waktu penelitian adalah waktu yang digunakan dalam melaksanakan penelitian. Pelaksanaan penelitian dilakukan dari bulan Januari 2019 sampai dengan bulan Mei 2019. Penelitian ini dilaksanakan pada Semester Genap pada Tahun Pembelajaran 2018/2019 yaitu dari bulan Januari 2019 sampai dengan Mei 2019.

\section{Rancangan/ Desain Penelitian}

Menurut Syaodih (2011: 5), penelitian diartikan sebagai suatu proses pengumpulan analisis data yang dilakukan secara sistematis dan logis untuk 
mencapai tujuan-tujuan tertentu". Dalam penelitian ini, desain penelitian korelasi bertujuan untuk mengetahui hubungan antara dua variabel atau lebih. Pada penelitian ini terdapat dua variabel yaitu variabel bebas dan variabel terikat.

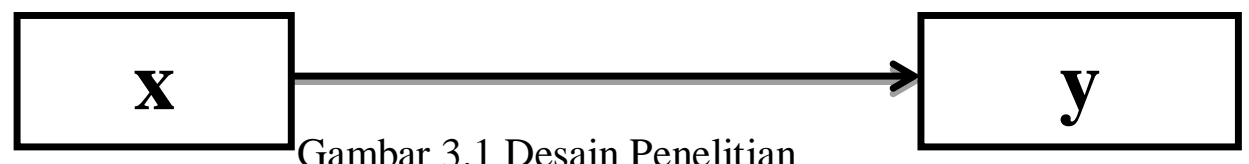

(Sugiono, 2018:42)

Keterangan:

$\mathrm{X}$ : Tingkat Pendidikan orangtua

Y : Motivasi Belajar

\section{Populasi dan Teknik Pengambilan Sampel}

\section{Populasi}

Dalam penelitian memerlukan populasi. Populasi adalah keseluruhan obyek penelitian. Menurut Arikunto (2010: 173), populasi adalah keseluruhan subjek penelitian. Selain itu, menurut Sugiyono (2018: 80), populasi adalah wilayah generalisasi yang terdiri dari obyek/subyek yang mempunyai kualitas dan karakteristik tertentu yang ditetapkan oleh peneliti untuk dipelajari dan kemudian ditarik kesimpulannya.

Berdasarkan beberapa pendapat para ahli di atas, dapat disimpulkan bahwa populasi adalah seluruh subjek di dalam wilayah penelitian yang dijadikan sebagai subjek yang ingin diteliti. Adapun yang menjadi populasi dalam penelitian ini adalah seluruh siswa SD Negeri 064025 Kecamatan Medan Tuntungan Tahun Pembelajaran 2018/ 2019 sebanyak 24 kelas. Adapun rincian populasi tersebut adalah sebagai berikut:

\section{Populai Penelitian}

\begin{tabular}{|c|c|c|c|}
\hline Kelas & Jumlah Siswa & Kelas & Jumlah Siswa \\
\hline Kelas I-A & 31 & Kelas IV-A & 31 \\
\hline Kelas I-B & 30 & Kelas IV-B & 31 \\
\hline Kelas I-C & 32 & Kelas IV-C & 32 \\
\hline Kelas I-D & 32 & Kelas IV-D & 30 \\
\hline Kelas II-A & 30 & Kelas V-A & 29 \\
\hline Kelas II-B & 30 & Kelas V-B & 30 \\
\hline
\end{tabular}




\begin{tabular}{|c|c|c|c|}
\hline Kelas II-C & 29 & Kelas V-C & 30 \\
\hline Kelas II-D & 30 & Kelas V-D & 31 \\
\hline Kelas III-A & 30 & Kelas VI-A & 32 \\
\hline Kelas III-B & 31 & Kelas VI-B & 32 \\
\hline Kelas III-C & 31 & Kelas VI-C & 31 \\
\hline Kelas III-D & 29 & Kelas IV-D & 30 \\
\hline \multicolumn{3}{|c|}{ Total $\mathbf{~ 7 3 4}$} \\
\hline
\end{tabular}

\section{Sampel}

Sampel adalah sebagian dari jumlah dan karakteristik yang dimiliki oleh populasi tersebut, ataupun bagian kecil dari anggota populasi yang diambil menurut prosedur tertentu. Menurut Arikunto (2010: 174), sampel adalah sebagian atau wakil populasi yang diteliti. Selain itu menurut Sugiyono (2018: 81), sampel adalah bagian dari jumlah dan karakteristik yang dimiliki oleh populasi tersebut. Berdasarkan populasi penelitian ini, maka peneliti menggunakan teknik pengambilan sampel Simple Random Sampling. Menurut Noor (2013: 151), teknik simple random samling adalah teknik yang paling sederhana. Sampel diambil secara acak, tanpa memperhatikan tingkatan yang ada dalam populasi, tiap elemen populasi memiliki peluang yang sama dan diketahui untuk terpilih sebagai subjek. Jumlah sampel yang digunakan sebanyak 124 siswa, yaitu siswa kelas IV SD Negeri 067246 Kecamatan Medan Tuntungan.

\section{Sampel Penelitian}

\begin{tabular}{|c|c|c|}
\hline No & Kelas & Jumlah \\
\hline 1 & IV-A & 31 \\
\hline 2 & IV-B & 31 \\
\hline 3 & IV-C & 30 \\
\hline 4 & IV-D & 124 orang \\
\hline & Total \\
\hline
\end{tabular}

\section{Jenis dan Sumber Data}

\section{Jenis Data}

Data adalah hasil pencatatan peneliti, baik yang berupa fakta maupun angka. Menurut Sugiyono (2018: 225), bila dilihat dari sumber datanya, maka pengumpulan data dapat menggunakan jenis data primer dan jenis sekunder. Data primer adalah sumber data yang langsung memberikan data kepada pengumpul data, dan data sekunder merupakan sumber yang tidak langsung memberikan 
kepada pengumpul data. Dalam penelitian ini jenis data yang digunakan oleh peneliti adalah jenis data primer yang langsung diperloleh dari subjek peneliti. Sumber data dalam penelitian ini adalah siswa kelas IV SD Negeri 064025 Kecamatan Medan Tuntungan Tahun Pembelajaran 2018/ 2019.

\section{Sumber Data}

Menurut Arikunto (2010: 172), sumber data dalam penelitian adalah subjek darimana data dapat diperoleh. Adapun sumber data dalam penelitian ini adalah siswa kelas IV SD Negeri 064025 Kecamatan Medan Tuntungan dan sumber data yang digunakan adalah sampel penelitian yaitu sebanyak 124 orang siswa.

\section{Teknik dan Alat Pengumpulan Data}

Teknik pengumpulan data merupakan cara yang digunakan peneliti untuk mengumpulkan data. Teknik pengumpulan data dapat dilakukan dalam berbagi seting, berbagai sumber dan berbagai cara. Dalam sebuat penelitian ada dua cara dalam melakukan teknik pengumpulan data, yaitu tes dan non tes. Pada penelitian ini peneliti memakai teknik pengumpulan data secara non tes. Dalam teknik pengambilan data secara non tes, peneliti memakai 3 (tiga) cara dalam teknik pengambilan data yaitu interview (wawancara), kuesioner atau angket dan observasi.

\section{Angket}

Merupakan suatu teknik pengumpulan data dengan memberikan atau menyebarkan daftar pertanyaan kepada responden. Menurut Sugiyono (2018:137) Kuuesioner merupakan teknik pengumpulan data yang dilakukan dengan cara memberi seperangkat pertanyaan tertulis kepada responden untuk dijawab. Pada penelitian ini peneliti memberikan angket kepada siswa yang akan dijawab oleh siswa. Pertanyaan atau pernyataan yang akan diberikan oleh peniliti kepada siswa nantinya berjumblah 50 butir (terlampir).

Pada penelitian ini peneliti menggunakan skala Guttman. Menurut Sugiyono (2018: 96), skala pengukuran dengan tipe ini akan didapat jawaban yang tegas, yaitu "ya-tidak", "benar-salah", "pernah-tidak pernah", dan "positifnegatif',. Selain dapat dibuat dalam bentuk pilihan ganda, juga dapat dibuat dalam 
bentuk checklist. Jawaban dapat dibuat skor tertinggi satu dan terendah diberi skor nol.

\section{Observasi}

Observasi merupakan teknik pengumpulan data dengan cara mengamati. Menurut Sugiyono (2018: 137) Observaasi sebagai teknik pengumpulan data mempunyai ciri yang spesifik bila dibandingkan dengan teknik yang lain, yaitu wawancara dan kuesioner. Peneliti melakukan observasi di SD Negeri 064025 Kecamatan Medan Tuntungan yaitu dengan mengamati siswa.

\section{Uji Kualitas Instrumen}

\section{Uji Validitas Angket}

Validitas adalah indeks yang menunjukan sejauh mana suatu alat ukur betul-betul mengukur apa yang perlu diukur. Menurut Arikunto (2010: 211), validitas adalah suatu alat ukur yang menunjukan tingkat-tingkat kevalidan atau kesahihan sesuai instrumen. Jika suatu instrumen pengukuran sudah valid (sah) berarti instrumen tersebut dapat mengukur benda dengan tepat sesuai dengan apa yang ingin diukur. Cara untuk mengukur validitas ini dapat dilakukan dengan mengkorelasikan antar skor yang diperoleh dari masing-masing butir angket dengan skor totalnya. Teknik yang dapat digunakan untuk menguji validitas alat ukur dalam hal ini yaitu dengan teknik Product moment (terlampir) dengan rumus sebagai berikut :

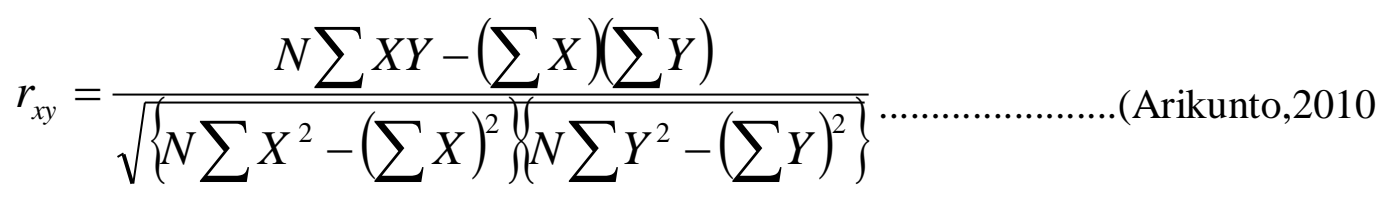

\footnotetext{
Keterangan :

Rxy $=$ Koefisien korelasi $\mathrm{x}$ dan $\mathrm{y}$

$\mathrm{N}=$ Jumlah responden / banyak siswa peserta tes

$\mathrm{X}=$ Jumlah skor diperoleh siswa untuk tiap item soal

$\mathrm{Y}=$ Jumlah skor total yang benar
} 
Untuk menentukan instrumen valid atau tidaknya maka diperlukan bantuan program SPSS Ver 18.0 adalah sebagai berikut:

1. Jika $r_{\text {hitung }} \geq r_{\text {tabel }}$ dengan taraf signifikan $0,5 \%$, maka instrumen tersebut dikatakan valid.

2. Jika $r_{\text {hitung }} \leq r_{\text {tabel }}$ dengan taraf signifikan $0,5 \%$, maka instrumen tersebut dikatakan tidak valid.

Berdasarkan hasil uji validitas skala uji coba yang diolah dengan menggunakan SPSS ver 22 diketahui bahwa dari 50 butir angket tingkat pendidikan orangtua ada 31 soal yang valid dan 19 soal yang tidak valid pada 124 responden, sehingga soal-soal yang valid dapat dipakai sebagai instrumen pengumpulan data untuk penelitian ini.

\section{Uji Reliabilitas}

Reliabilitas digunakan untuk mengukur suatu kuisioner. Butir pertanyaan dikatakan reliabel atau andal apabila jawaban seseorang terhadap pertanyaan adalah konsisten. Hasil penelitian yang reliable, bila terdapat kesamaan data dalam waktu yang berbeda, instrument yang reliabel adalah instrument yang bila digunakan beberapa kali untuk mengukur objek yang sama, akan menghasilkan data yang sama.

Adapun rumus dari reliabilitas menggunakan rumus Alpha menurut Arikunto (2010: 239), adalah sebagai berikut:

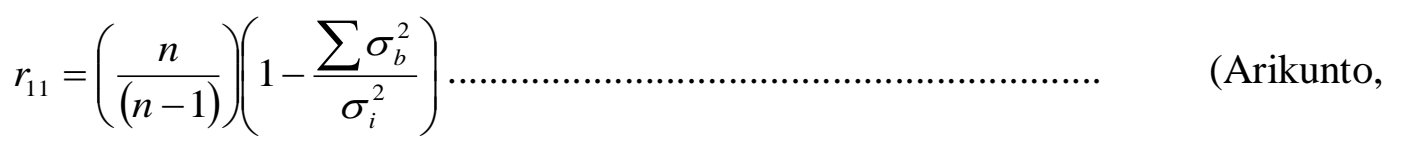

\section{0: 122)}

\section{Keterangan:}

$r_{11}=$ Reliabilitas tes yang dicari

$\sum \sigma_{b}^{2}=$ Jumlah varians skor tiap-tiap item

$\sigma_{i}^{2}=$ Varians total

$\mathrm{n} \quad=$ Banyaknya butir pertanyaan

Untuk mencari varians item digunakan rumus: 


$$
\sigma_{b}^{2}=\frac{\sum x-\frac{\left(\sum x\right)^{2}}{N}}{N}
$$

(Arikunto,

\section{6: 23)}

Keterangan:

$\mathrm{N}$ = Banyaknya siswa peserta tes

$\sigma_{b}^{2}=$ Varians tiap item

$\mathrm{X}=$ Nilai tiap butir soal

Dan untuk mencari varians total $\left(\sigma_{t}^{2}\right)$ dipergunakan rumus sebagai berikut:

$$
\sigma_{t}^{2}=\frac{\sum Y^{2}-\left(\sum Y\right)^{2}}{N} .
$$

(Arikunto,

\section{6: 23)}

Keterangan:

$\mathrm{N}$ = Banyaknya siswa peserta tes

$\sigma_{t}^{2}=$ Varians total

$\mathrm{Y}^{2}=$ Nilai total butir soal

Interpretasi koefisien reliabilitas terhadap hasil perhitungan nilai koefisien korelasi $r_{11}$ mengacu pada pendapat Arikunto (2016: 89) sebagai berikut:

\section{Pedoman Untuk Interpretasi Terhadap Koefisien Reliabilitas}

\begin{tabular}{|c|c|}
\hline Interval Koefisien & Tingkat Hubungan \\
\hline $0,00-0,199$ & Sangat rendah \\
$0,20-0,399$ & Rendah \\
$0,40-0,599$ & Sedang \\
$0,60-0,799$ & Kuat \\
$0.80-1,000$ & Sangat kuat \\
\hline
\end{tabular}

\section{Hasil reliabilitas motivasi belajar}

Reliability Statistics

\begin{tabular}{|r|r|r|}
\hline Cronbach's Alpha & \multicolumn{1}{|c|}{$\begin{array}{c}\text { Cronbach's Alpha Based on } \\
\text { Standardized Items }\end{array}$} & N of Items \\
\hline .868 & .906 & 31 \\
\hline
\end{tabular}


Hasil perhitungan uji reabilitas instrumen soal dengan menggunakan program SPSS ver. 22. Uji reabilitas angket motivasi belajar dilakukan dengan menggunakan rumus alpha. Hasil perhitungan diperoleh indeks reliabilitas instrumen sebesar 0,906. Dari hasil perhitungan data tersebut dapat disimpulkan bahwa instrumen yang digunakan reliabel karena memiliki indeks reliabelitas kategori tinggi.

\section{Uji persyaratan Analisis Data}

Dalam penelitian kuantitatif, analisis data merupakan kegiatan setelah data dari seluruh responden atau sumber data lain terkumpul. Menurut Sugiyono (2018: 137), teknik pengumpulan data dapat dilakukan dalam berbagai setting, berbagai sumber dan berbagai cara. Tujuan utama dalam penelitian ini adalah untuk mendapatkan data.

1. Uji Normalitas

Statistik parametris mensyaratkan bahwa setiap variabel yang akan dianalisis harus berdistribusi normal, maka sebelum pengujian hipotesis dilakukan terlebih dahulu pengujian normalitas data. Untuk mengukur signifikansi normalitas dapat menggunakan Chi Square. Uji normalitas dilakukan pada kedua variabel yang akan diteliti. Variabel bebas (X) adalah Tingkat pendidikan orang tua, dan variabel terikat (Y) adalah motivasi belajar siswa. Rumus yang digunakan adalah rumus Chi kuadrat $\left(\mathrm{X}^{2}\right)$, yaitu:

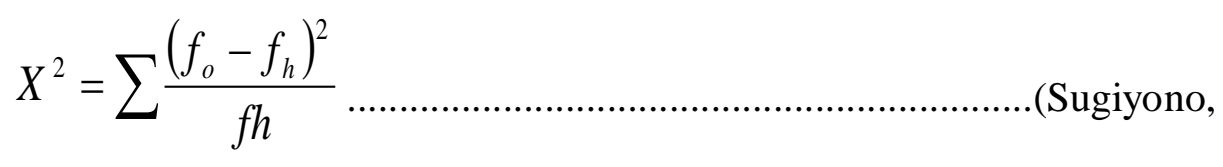

2017: 214)

Keterangan:

$\mathrm{X}^{2}=$ Chi-kuadrat

$\mathrm{f}_{\mathrm{o}}=$ Frekuensi yang diharapkan

$\mathrm{f}=$ Frekuensi yang diobservasi

2. Linieritas

Uji linearitas bertujuan untuk mengetahui apakah dua variabel mempunyai hubungan yang linear atau tidak secara signifikan. Uji ini biasanya 
digunakan sebagai prasyarat dalam analisis korelasi atau regresi linear. Adapun rumus Uji Lineritas adalah sebagai berikut :

$\mathrm{Y}=\mathrm{a}+\mathrm{Bx}$

Keterangan :

$\mathrm{a}=$ konstata

$\mathrm{B}=$ koefisien regresi

$\mathrm{X}=$ variabel independen

$\mathrm{Y}=$ Variabel dependen.

\section{Uji Hipotesis}

Pada penelitian ini, uji t digunakan untuk mengetahui sejauh mana variabel tingkat pendidikan orangtua mampu menjelaskan pengaruh terhadap motivasi belajar Dengan berbantukan program SPSS Versi 22.0.

$\mathrm{T}_{0}=\frac{M 1-M 2}{S E M 1-M 2}$ .(Sudijono, 2012:

297)

Keterangan:

$\mathrm{T}_{0}=$ Nilai hasil perhitungan

$\mathrm{M}_{1}=$ Mean dari kelompok I

$\mathrm{M}_{2}=$ Mean dari kelompok II

$\mathrm{SE}_{\mathrm{M} 1-\mathrm{M} 2}=$ Standar error perbedaan kedua kelompok

Hipotesis diterima, jika $t_{\text {hitung }}>\mathrm{t}_{\text {tabel }}$ begitu sebaliknya, jika $t_{\text {hitung }}<\mathrm{t}_{\text {tabel }}$ maka hipotesis ditolak. Dengan taraf kesalahan 5\%.

\section{Prosedur Penelitian}

Prosedur penelitian ini dilakukan di SD Negeri 064025 Kecamatan Medan Tuntungan sebagai tempat untuk meneliti. Adapun tahap-tahap dalam melakukan prosedur dalam penelitian ini adalah sebagai berikut:

1. Tahap Persiapan

Kegiatan yang dilakukan dalam tahap persiapan ini adalah mempersiapkan segala yang berhubungan dengan pelaksanaan penelitian. Dalam kegiatan ini diharapkan pelaksanaan penelitian akan berjalan lancar dan mencapai tujuan yang diinginkan. 
2. Tahap Pelaksanaan

Yang perlu dilakukan pada tahap ini adalah:

a. Pada tahap pelaksanaan ini, kegiatan yang dilakukan yaitu menyebarkan angket, dalam hal ini yang perlu dilakukan peneliti adalah memberi penjelasan sedikit bagaimana cara mengisi angket yang diberikan dan membimbing siswa untuk mengisi angket yang telah diberikan.

b. Mengumpulkan lembar angket yang telah diisi

3. Tahap akhir yaitu tahap menarik kesimpulan

\section{HASIL PENELITIAN DAN PEMBAHASAN}

\section{Pembahasan hasil temuan}

Penelitian ini dilakukan di SD Negeri No. 064025 Kecamatan Medan Tuntungan. Penelitian menggunakan kuesioner sebagai alat pengumpulan data dengan jumlah sampel penelitian sebanyak 124 peserta didik sampel. Tujuan peneliti melakukan penelitian ini untuk mengetahui pengaruh tingkat pendidikan orangtua dengan motivasi belajar siswa di SD Negeri 064025 Kecamatan Medan Tuntungan.

\section{a. Tingkat Pendidikan Orangtua Siswa Kelas IV SD Negeri 064025 Kecamatan Medan Tuntungan}

Setelah melakukan prosedur penelitian, meminta data tingkat pendidikan orangtua siswa kelas IV SD Negeri 064025 Kecamatan Medan Tuntungan untuk melihat tingkat pendidikan orangtua siswa dan hasil yang diperoleh menunjukkan bahwa tingkat pendidikan orangtua siswa sangat rendah hal ini terbukti dari hasil data yang sudah diperoleh yaitu SD sebanyak 30 orang, SMP sebanyak 40 orang, SMA sebanyak 20 orang, D3 sebanyak 19 orang dan S1 sebanyak 15 orang. Berdasarkan hasil identifikasi yang paling banyak adalah tingkat pendidikan SMP. Oleh karena itu tingkat pendidikan orangtua siswa di SD 064025 masih rendah.

\section{b. Motivasi Belajar Siswa Kelas IV SD Negeri 064025 Kecamatan Medan Tuntungan}

Setelah melakukan prosedur penelitian, membagikan angket motivasi belajar yang dilakukan pada siswa kelas IV SD Negeri 064025 hasil yang 
diperoleh menunjukkan bahwa motivasi belajar siswa dapat dikategorikan berdasarkan tingkat pendidikan orangtuanya yaitu SD dengan kategori cukup, SMP dengan kategori cukup, SMA dengan kategori cukup, D3 dengan kategori tinggi dan S1 dengan kategori tinggi. Berdasarkan hasil identifikasi menunjukkan bahwa semakin tinggi tingkat pendidikan orangtua maka semakin tinggi pula motivasi belajarnya.

\section{PENUTUP}

\section{Kesimpulan}

Berdasarkan hasil analisa data dalam Bab IV dari penelitian yang berjudul "pengaruh tingkat pendidikan orangtua dengan motivasi belajar matematika siswa di kelas IV SD Negeri 064025 Kecamatan Medan Tuntungan” diperoleh kesimpulan:

1. Mayoritas tingkat pendidikan orangtua (ayah) siswa kelas IV di SD Negeri 064025 Kecamatan Medan Tuntungan cenderung tamat SMP sebanyak 40 orang $(32,26 \%)$.

2. Hasil penelitian di SD Negeri 064025 Kecamatan Medan Tuntungan menunjukkan bahwa tingkat pendidikan memiliki pengaruh terhadap motivasi belajar siswa.

3. Terdapat pengaruh yang positif dan signifikan tingkat pendidikan orangtua terhadap motivasi belajar siswa dalam pembelajaran Matematika di kelas IV SD Negeri 064025 Kecamatan Medan Tuntungan yang dibuktikan dari hasil pengujian hipotesis yaitu $t_{\text {hitung }}>t_{\text {tabel }}$ yaitu SD dengan $\operatorname{SMP~(2,2937>~}$ 1,6675), SD dengan SMA (5,3917> 1,6722), SD dengan D3 (2,2635> 1,6779), SD dengan $\mathrm{S} 1(2,0929>1,6810$.

\section{Saran}

Berdasarkan hasil penelitian yang telah dipaparkan, maka saran yang dapat disampaikan oleh peneliti adalah sebagai berikut:

1. Bagi sekolah

Sekolah khususnya guru harus memberikan motivasi dan bimbingan lebih kepada siswa untuk lebih giat belajar walaupun di rumah kurang mendapatkan bimbingan dari orang tua. 
2. Bagi siswa

Dengan mengetahui adanya hubungan tingkat pendidikan orangtua dengan motivasi belajar siswa, siswa diharapkan mempunyai motivasi sendiri untuk mengembangkan prestasinya di bidang akademik maupun non akademik tanpa harus tergantung pada orang tua.

3. Bagi Peneliti

Supaya dapat mengkaji lebih lanjut tentang hubungan tingkat pendidikan orangtua dengan motivasi belajar seswa. Dengan penelitian tersebut diharapkan dapat ditemukan hubungan yang dapat dilakukan agar siswa memiliki motivasi belajar yang tinggi.

\section{DAFTAR PUSTAKA}

Arikunto, Suharsimi. 2010. Prosedur Penelitian. Jakarta: Rineka Cipta.

Darmawati, Iis. 2012. Hubungan Tingkat Pendidikan Orang tua Terhadap Motivasi Belajar siswa dalam Pembelajaran Matematika Kelas V SD Negeri No. 106193 Desa Bakaran Batu Kecamatan Pantai Cermin. Medan. Skripsi

Ferdinan, Jon. 2012. Hubungan Tingkat Pendidikan Orang tua terhadap Kenakalan Remaja di Kelurahan Bane Kecamatan Siantar Utara Pemarang Siantar. Medan. Skripsi.

Hamdani, 2011. Dasar-Dasar Kependidikan. Bandung: Pustaka Setia.

.M. A, 2011. Strategi BelajarMengajar. Bandung: Pustaka Setia.

Hamzah. 2016. Teori Motivasi dan Pengukurannya. Jakarta: Bumi Aksara.

Hasbullah. 2015. Dasar-dasar Ilmu Pendidikan. Jakarta: PT. Rajagrafindo Persada.

Ihsan, Fuad. 2010. Dasar-dasar Kependidikan. Jakarta: PT. Rineka Cipta.

Kadir, Abdul. dkk. 2017. Dasar-dasar Pendidikan. Jakarta: Kencana.

Khairani, Makmun. 2016. Psikologi Belajar. Yogyakarta: Aswaja Pressindo.

Milfayetty, Sri. dkk. 2018. Psikologi Pendidikan. Medan.

Noor, Juliansyah. 2013. Metodologi Penelitian. Jakarta: Kencana 
Pulungan, Intan dan Istarani 2017. Ensiklopedi Pendidikan. Medan: Media Persada.

Sardiman. 2010. Interaksi dan Motivasi Belajar-Mengajar. Jakarta: Rineka Cipta.

Selfia. 2018. Peran Orang Tua Meningkatkan Motivasi Belajar Peserta Didik di SD Negeri Saribi. Vol. 2. No. 2. Jurnal

Shochib, Moh. 2018. Pola Asuh Orangtua. Jakarta: Rineka Cipta.

Siregar, Syofian. 2015. Statistika Terapan. Jakarta: Prenadamedia Group.

Sudijono, Anas. 1987. Pengantar Statistik Pendidikan. Jakarta: Rajawali Pers

Slameto. 2010. Belajar dan Faktor-faktor yang Mempengaruhi. Jakarta: Rineka Cipta.

Soemarmo dan Hendriana. 2016. Penilaian Pembelajaran Matematika. Bandung: PT. Refika Aditama.

Sriwilujeng. 2017. Pendidikan karakter. Jakarta: Erlangga

Sugiyono. 2018. Metode Penelitian. Bandung: Alfabeta

Susanto, Ahmad. 2014. Teori Belajar dan Pembelajaran di Sekolah Dasar. Jakarta: Prenamedia Group.

Syah, Muhibbin. 2017. Psikologi Pendidikan. Bandung: PT. Remaja Rosdakarya.

Syaodih, Nana. 2011. Metode Penelitian Pendidikan. Bandung: PT. Remaja Rosdakarya.

Widodo, Ariyo. 2015. Hubungan Tingkat Pendidikan Orangtua dengan Motivasi Belajar Siswa Kelas V. Yogyakarta. Skripsi 